\title{
患者体表面へのプローブ接触力を考慮した遠隔超音波診断システムのための インターフェースの開発
}

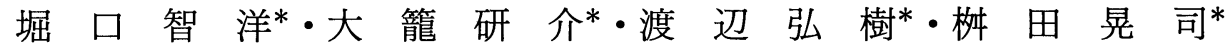
Development of Tele-echography Interface Considering Contact Force of Ultrasound Probe to Body Surface

\author{
Tomohiro Horiguchi*, Kensuke Ookomori*, Hiroki Watanabe* and Kohji Masuda
}

\begin{abstract}
We have developed a human interface for medical doctor to control a remote diagnosis robot by a controller in tele-echography. We have completed signal and image communication between the robot and controller. The remote doctor was able to sense restitution force on patient's body surface by introducing bilateral control method. However, not only the position of the ultrasound probe but also the positional relationship between the probe and body surface were difficult to understand because all information for the doctor was on the remote monitor. Therefore we have reconstructed all the environment of the patient's body shape and the probe to be visualized as computer graphics (CG) using OpenGL. To evaluate delay time, the both positions of the probe and the actual handle were visualized on the same GUI window. To calculate the distance between the probe and the patient for safe control of the robot, precise shape of body surface was measured by detecting contact force on body and was reconstructed by introducing Delaunay triangulation method. We have also designed the console window including echogram, patient scene and CG with automatic control of image quality by considering contact force. We have confirmd operativity of the interface through actual remote diagnosis of tele-echography.
\end{abstract}

Key Words : tele-echography, interface, contact force

\section{1. まえがき}

超音波診断は，医師が超音波プローブを手にもち，患者の 体表に押し当てるだけで生体内部の断層像や血流の情報が得 られる診断法で，その便利性と非侵襲性(体に傷をつけない) によって幅広く用いられている. 最近はノートPCタイプの ポータブル超音波診断装置も普及しており，診断する場所を 選ばない画像診断法として認知されつつある. 一方, 高齢化 社会に伴う在宅医療に対する関心の高まり, 医療機関の都市 部集中による過疎地域, 離島での医師不足などから遠隔医療 の必要性が叫ばれ, 実施例も多数報告されている.X 線 CT やMRI といった他の画像診断法と比較するまでもなく, 携 帯性, 安全性という点において, 遠隔医療に導入できる画像 診断法は現状では超音波以外に考えられない。 そのため, 医 師と患者が離れた状態でネットワークを介して診断を行なう 遠隔超音波診断(テレエコー) システムについて,さまざまな

* 東京農工大学大学院生物システム応用科学府 小金井市中町 2 丁目 24 番

* Graduate School of Bio-Applications and Systems Engineering, Tokyo University of Agriculture and Technology, 2-24 Naka-cho, Koganei

(Received February 1, 2008)

(Revised June 2, 2008)
研究が行なわれてきた. Blaivas ら ${ }^{1)}$ は救急時の超音波画像 の伝送，末永ら ${ }^{2)}$ は医師からの指示を映像化した遠隔診断環 境を構築した。特に後者のシステムでは，医師が患者側の映 像を見ながらプローブ操作の指示を出し，患者側の技師が患 者体表面にプロジェクタで投影された CG マーカーと音声に 従いプローブ操作を行なうものである。しかし遠隔地の医師 の指示を技師が忠実に再現するには限界があり，また医師は 体表面への接触力を感じ取れないため，プローブを押し当て て画像を得た経験を活かせず，思いどおりの画像を取得する ことができなかった。

一方，患者側にプローブを把持したロボットを設置する遠 隔診断システムも考案され，われわれが開発してきた臥位の 患者をまたぐような形状の小型軽量パラレルリンク型ロボッ 卜3),4) だけでなく，小泉らの透析肩の診断のための大型口 ボット5),6)，またVilchis らの 4 方向からのベルト伸縮によ る腹部搭載型ロボット7), Abolmaesumi らのシリアルリン クによる頝部診断ロボット8) などが開発された。遠隔診断に ロボットを導入することによって，プローブ位置制御の点で は向上が見られた。しかし遠隔地の患者状況の把握には限界 があり, 患者への安全面での配慮や，特に患者体表面への急 激な接触を避けるような補助機能が不足していた。

前述した多くの研究では, 患者体表面での接触を感知する 
ために市販の力覚呈示デバイスなどを導入している.われわ れは，遠隔超音波診断専用のパラレルワイヤ駆動を用いた医 師側操作コントローラ゙9) を開発し，遠隔操作を含めた通信実 験 ${ }^{10)}$ を行なってきた. 力覚フィードバックについては成果 が得られた ${ }^{11)} も の の ，$ 視覚情報についてはカメラで捉えた 患者側の映像を参照していたため, 患者とプローブとの位置 関係の把握は不十分であり，ネットワークの遅延に起因する 位置ずれがある状況では実際の運用は困難であった。よっ て，コントローラの指令に対するロボットの状況を正確にモ ニタリングし，視覚的に遠隔操作を支援するシステムの開発 が必要とされた。

以上のような背景をもとに，われわれはバーチャルリアリ ティで用いられる手法を導入して患者側の環境を医師側に再 現することにより，操作者が視覚的に遅延，位置追従誤差を 確認でき，また患者体表面とプローブの位置関係の把握が容 易となる環境を設計・開発した。さらに追加機能として，ロ ボットとコントローラの状態を自動的に判断し，超音波画像 と患者が映った画像との間で転送速度を考慮し，診断状況に 応じて映像間の相対的品質を制御する遠隔超音波診断のため のインターフェースを構築した。以下に詳細を述べる.

\section{2. 遠隔超音波診断システムの構成要素}

\section{1 操作コントローラとカ呈示}

Fig. 1 は操作コントローラ99)の外観で, パラレルワイヤ駆 動機構を用いて操作時の空間を確保し，通常の診断と同様の プロープ操作を可能にした. ワイヤ駆動機構とは制御対象物 につながれたワイヤの他端と固定されたアクチュエータ部を つなぎ，ワイヤ長をモータで調節することにより対象物の位 置を制御するものである. 医師が操作するハンドルの上下に それぞれ 3 本ずつワイヤを取り付け，周囲の 6 個のアクチュ エータ部と接続される。アクチュエータ部はモータ，センサ などから構成され，ワイヤ張力が指定の值に落ち着くように ワイヤ長を制御する. 計測されたワイヤ長から, ハンドルの 3 次元位置と 2 次元回転角の計 5 自由度の情報を取得し, こ れをリアルタイムで患者側ロボットに送信する。ハンドルの 軸回転角については，ハンドルそのものに取り付けられた角 度センサで独自に検出している. 各ワイヤ張力はForce

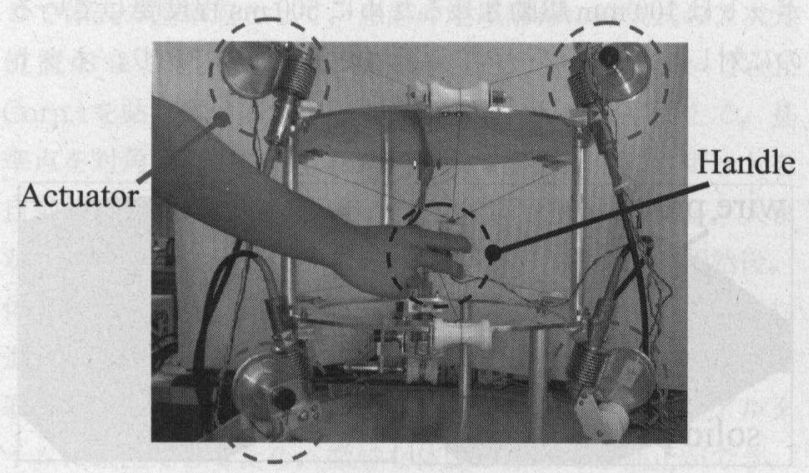

Fig. 1 Outlook of the controller
Closure 理論 ${ }^{12)}$ により制御され，操作者は体表に押し当てた 接触力を数 10-2000 gf 程度の範囲で感知することができる. ハンドルの可動範囲は, 直径 $200 \mathrm{~mm}$, 高さ $150 \mathrm{~mm}$ 程度の 円筒内である.

\section{2 患者側検査ロボットと力検出}

Fig. 2 に患者側検査ロボット ${ }^{3), 4)}$ の外観を示す. 本ロボッ トはプローブ保持部を 3 本の脚の先端で支える構造で, 脚 1 本に付き 3 個のアクチュエータが取り付けられており，全体 で 9 自由度の複雑な 3 次元運動を可能とした。脚の基部は ベッドの端に自由に配置することが可能で，心臓の場合は左 寄りに脚を 2 本，というように観察する対象によって構造を 変化させることができる.各脚の関節には角度センサが付い ているため, ロボットの構造と運動学からプローブ先端の現 在位置を計算している.さらに患者体表面への接触力を検知 するため，図中に示すプローブ保持部に 3 軸力覚センサを取

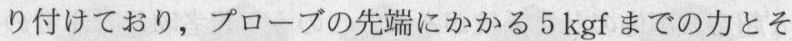
の方向を算出することができる. 実際に，医師が患者の体表 にプローブを押し付ける力を計測したところ，胸部では数

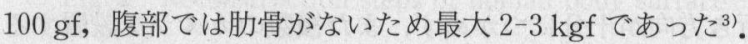

\section{3 位置指令值と接触力の通信手法}

遠隔操作の指令值信号は不測のデータ欠損が起こりにくい 通信システムを構築する必要があるため，信頼性の高い TCP/IP の通信プロトコルでWinsock という API を使用し て, 両ハードウェア間のデータを送受信する通信プログラム を開発した ${ }^{13)}$. Winsock は通常，ブロッキングモードに設 定されており，データの受信を待機している側が，受信の完 了まで他の処理を行なえないため，ロボット側の更新周期が 低下し，ロボットの動作が鈍って安全性が損なわれる問題が 生じた.そこでデータが届かなくてもフリーズせず，それ以 降の処理も行なえるノンブロッキングモードを用いることに より，通信が途絶えた場合でも途切れる寸前の位置指令を保 つ処理プログラムを構築し, 患者への安全性を高めることに 成功した．また受信側で処理が追いつかず，データがたまっ ていくことにより動作遅延が起きる場合には，データの蓄積 を判定し，最新データのみを抽出することにより受信側にた まった遅延を解消するプログラムを作成した。これによりど んな送受信状態であっても，ネットワークによる動作遅延を

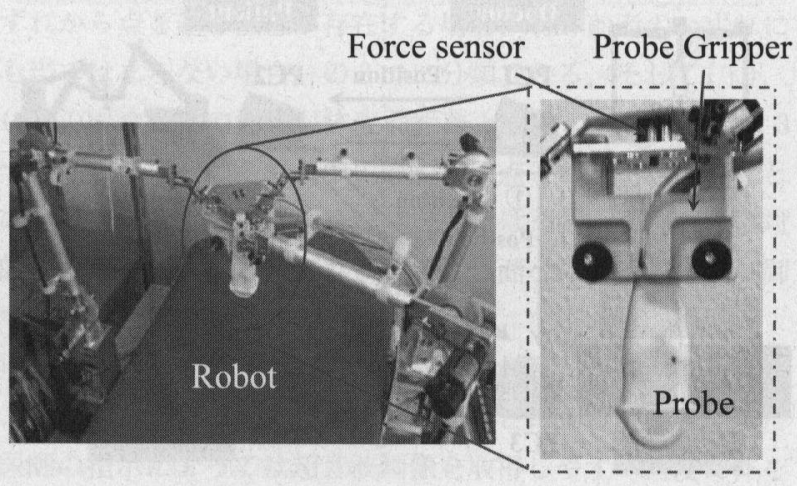

Fig. 2 Outlook of the robot and the probe gripper part 
最小限に抑えた遠隔操作を可能とした。一方，その場合は不 連続な指令值をロボットに与えることを防ぐため，デー夕を 補間する機能が必要となる。

\section{3. ユーザインターフェースの設計}

本研究における診断システムの構成を Fig. 3 に示す．前 述のコントローラと検査ロボットはそれぞれ制御用 PC 1 と PC 2 に接続されており, 基本的な制御信号の流れとして, PC 1 からはハンドルの 3 次元位置および角度である指令值 を，PC 2 からはプローブ保持部の力センサ出力を変換した プローブ先端の接触力を互いにやり取りする。これとは別 に，患者側の診断画像を医師側に伝送する必要があるが，本 稿では映像通信用 PC を医師側，患者側に設定し，それぞれ PC 3，PC 4 として制御用 PC から独立させて記述した。ま た診断画像には患者のようすが映った映像 (以下，患者映像) と超音波画像の計 2 系統がある.このうち患者映像は患者の 急激な容態変化などに対応するため，省略することはできな いが， 1 台のカメラではプローブと体表面の位置関係，特に 奥行き方向が十分につかめず，また複数のカメラを設置する と切り替え操作が必要となり, 伝送量が増大するという問題 が生じる. 複数映像を受信側で効率よく切り替える研究 ${ }^{14)}$ も行なわれているが，ここでは患者体表面へのプローブ先端 の接触から得られる情報をもとに，患者側の環境を医師側に $\mathrm{CG}$ (コンピュータグラフィックス)として再構成することを 目指した。これにより，プローブと体表面の詳細な位置関係 は通信帯域が少ない CG から得られることとなり，患者映像 は固定カメラからの1系統ですむ.

ここで CG に反映させる情報として，以下の 2 つの機能を 設計し，信号の流れを Fig. 3 中に示す.

(1)医師側のハンドルおよび患者側のプローブ位置の同時表 示による遅延時間の可視化

(2)プローブ先端の接触力とその分布計測による患者体表面 形状の再構成

前者はコントローラとロボットの位置情報を，後者はロ ボットから得られた接触力を映像化するもので，両方とも PC 3 に統合される.PC 3 には 2 系統の映像と CG の情報が

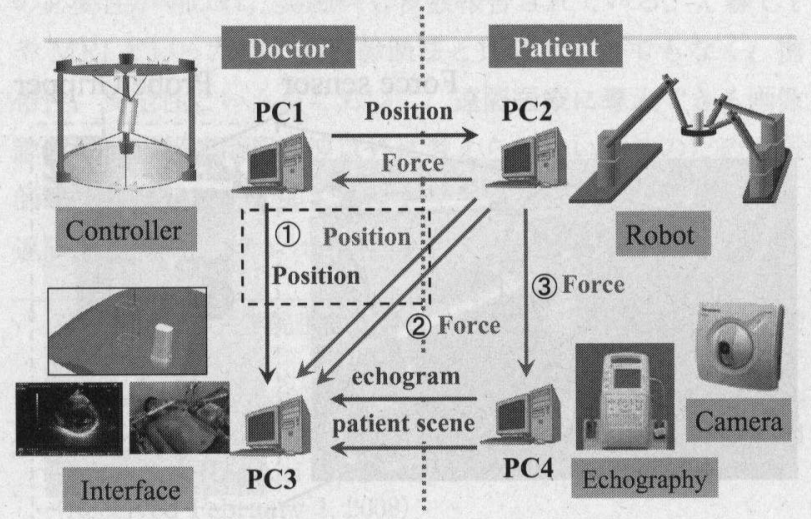

Fig. 3 System configuration of tele-echography
集中するため, 処理能力の高い PC を用いる必要がある。一 方, 2 系統の映像は一連の診断過程において常時必要なわけ ではない.つまりプローブが体表面に接触するまでは患者映 像が重要であり，接触後は超音波画像の変化を観察しながら プローブを操作することが主要なタスクとなる.よって,プ ローブの接触状態に応じて PC 4 から PC 3 に伝送する映像 の品質を制御することによって, 状況によって医師に必要な 情報を提供すると共に，PC 3 で処理すべき情報量を削減で きる.これは Fig. 3 中で示したように，

(3)プローブ先端の接触力検出による診断状況に応じた映像 品質制御

として機能する，以下，それぞれの機能とその詳細につい て述べる。

\section{4. 遅延時間の可視化}

ロボットを遠隔操作する場合は，ネットワークに起因する 遅延とロボットの動作遅延が必ず存在し，この 2 つを考慮に 入れて操作することが必須となる。しかも，操作中に遅延時 間が変動することもあり得るため, 連続的な遅延状況の把握 が必要である.そこで Fig. 3 の11に示したように, コント ローラのハンドルと，ロボットに把持されたプローブの両方 の相対的な位置関係を, PC 3 の同一の画面上に OpenGL と 呼ばれるグラフィックライブラリを用いて描画し，任意の視 点から位置追従を確認できるアプリケーションを開発し た ${ }^{10)}$ ，PC 3 では，PC 1，PC 2 からの受信デー夕を識別し， 受信と描画の 2 つの処理はマルチスレッドを用いてプログラ ムを作成することにより，並列処理を行なわせた．Fig. 4 に 示すように, コントローラからの指令值をプローブの外枠 (wire probe)，ロボット側から得られる実際のプローブの位 置を実体 (solid probe) として表示し, 遅延の度合を両者間 の距離として視覚的に評価できるようにした. solid probe の座標は最新のプローブ位置座標を反映しており, solid probe と wire probeの差がそのままネットワークとロボッ 卜駆動時間を含めた遅延時間となるため，医師はロボットの 追従を確認しながら操作できる。

ところで，この実験系では solid probe と wire probe の差 はネットワークを往復した，つまり本来把握したい遅延時間 の 2 倍表現していることになる.これについては，現状の口 ボットは $100 \mathrm{~mm}$ 駆動させるために $500 \mathrm{~ms}$ 程度要している のに対し,ネットワークの遅延は数 $\mathrm{ms}$ 程度であり,ネット

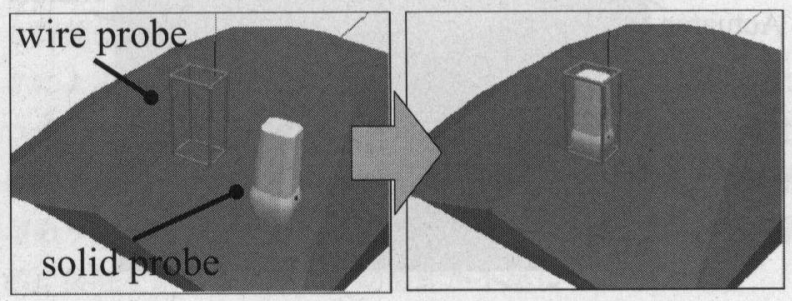

Fig. 4 Visualization of position delay of the probe 
ワークに対してロボット駆動に起因する遅延のほうが大き い.また，超音波診断の性格上，プローブを急激に動作させ ることは考えられないため, 安全性を高める一方問題とはな らない.

\section{5. プローブ接触力による患者体表面再構成}

\subsection{Delaunay 三角形分割による体表面再構成}

Fig. 3 の(2)に示した患者体表面構成については, プローブ 先端の体表面接触力が指定された閾值を超えたときのプロー ブ位置座標を検出し，Delaunay(ドロネー)三角形分割15) 17) の手法を応用してグラフィックを表示した。これは与えられ た複数の点を頂点とする三角形のうち，その三角形の外接円 に頂点以外のどの点も含まずに三角形を分割する手法であ り，3 次元モデルを生成する際にバーチャルリアリティの分 野で利用される。この Delaunay 三角形分割の中でも，サン プル点が増えるに従い，新たな三角形を生成して全体を再構 築していく逐次添加法 ${ }^{18)}$ を採用した。 逐次添加法では，三 角形を 3 つの新たな三角形に分割して対角線の入れ変え操作 を行なうことで, 最適な三角形のメッシュ構造を構築できる ため,この手法を $x, y, z$ の 3 次元空間に拡張し体表面を表 現することとした ${ }^{19)}$.

グラフィックを構成するための体表面座標は, プローブ先 端の体表面接触力に複数の閾值を設定し，それらが検出され た空間の分布から算出した.まず，体表面位置座標とプロー ブ接触力は線形性があると仮定した上で， 1 回の押し込みに より各接触力が検出されたそれぞれの体表面座標を計測し， それらから体表の弾性係数(バネ定数)を最小二乗法により算 出した. そして, 弾性係数から接触前の体表面座標を推定し た.ここで，超音波検査などの実験で用いられる胴体ファン トム (CIRS 057 ：以下ファントム)について接触力の閾值を $100,300,500 \mathrm{gf} の$ 三段階に設定して計測し，接触前の表面 を推定した.これを，前節と同様に OpenGLにより 3 次元 再構成したグラフィックを Fig. 5 に示す。

実際にベッドに臥位の患者の体表面形状を再構成する際, 取得点が多いほど精細な体表の形状を描画することができる が，診断時以外のプローブとの接触は患者に対して心理的な ストレスを余計に与えてしまう可能性がある.そのためでき るだけ少ない取得点で体表面を作成することが望ましい.そ こで体表の基準点として, 患者の鳩尾部分に磁気式の 3 次元 位置および姿勢センサ (microBIRD, Ascension Tech. Corp.）を貼り付ける. そしてべッド面に平行な平面上で，基 準点を対角線の中心とした四角形の 4 つの頂点にロボットを 自動的に移動させて, 各点での接触力と座標を計測し, 大ま かな体表面を形成して診断の準備段階とした. 診断開始後, 体表との接触を検出するたびに点を取得，随時体表データに 追加し, 検査の進行に伴い精細な体表を作成していく手法を 取った. 鳩尾部の基準点座標は位置センサによってリアルタ イムに検出できるため，微妙な体動があっても補正ができ， またロボットが不用意に鳩尾部を圧迫してしまうことを防ぐ

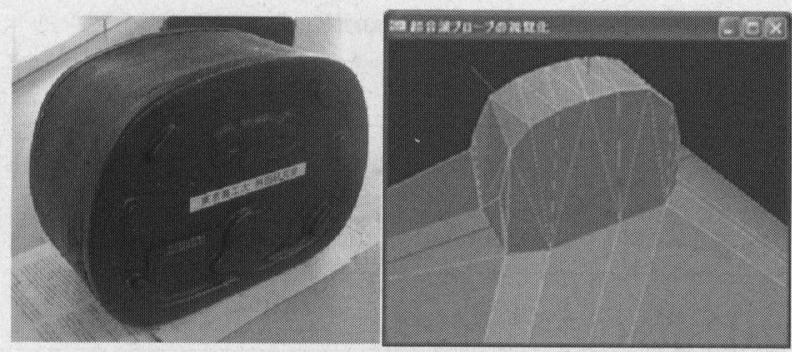

Fig. 5 Reconstructed shape of body phantom

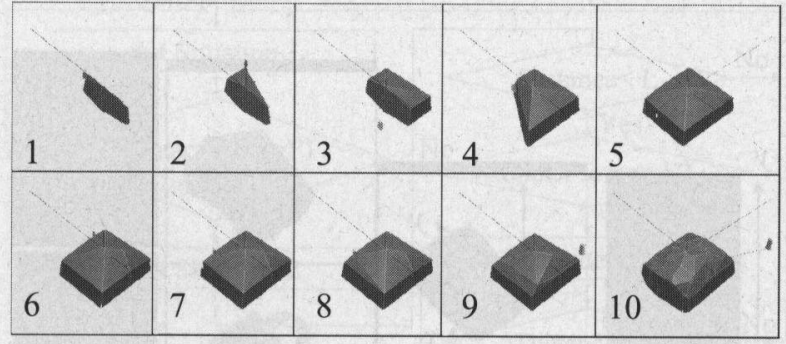

Fig. 6 Reconstruction steps of human body surface

ことができる。

Fig. 6 に実際に人間に適用した体表面形状の再構成の結果 を示す．被験者は 20 代，瘦せ型の男性である。基準点を含 む 5 点程度で大まかな体表が描けており, 計測点の増加に伴 い，体表面が形成されていくようすがわかる。ここでは基準 点以外の 4 点はベッド面上で 1 辺 $30 \mathrm{~cm}$ の正方形としたが, 実際の遠隔診断では観察対象となる藏器の位置や患者の体型 などに合わせる必要がある。

\section{2 プローブと体表面距離の算出}

遠隔診断において患者の安全を確保するためには，プロー ブと体表面の相対的位置関係を表現する指標が必要である. そこで上記の手法で生成した体表面と，プローブ先端座標と の距離を算出するアルゴリズムを確立した ${ }^{20)}$.これは生成さ れた体表面に含まれる 1 つの三角形とプローブ先端座標との 最短距離を算出し，同様の処理をすべての三角形に実行する ことで最終的な体表面距離を算出する手法を取る。このよう すを Fig. 7 に示す.点と三角形の距離は，（i ) 三角形から 点を通る法線が存在する場合，（ii）（i ）を満たさず 3 辺のい ずれから点を通る法線が存在する場合，（iii）前者のいずれに も当てはまらない場合，の 3 つに分類できる。 そして (i )， （ii）の場合はその法線が体表面距離となり，（iii）の場合は 3 つの頂点と点との距離の中で最短の頂点との距離を体表面と の距離とする。これによりモニタ上では不明確な両者の相対 的な距離を評価でき，プローブの体表面への接近方法を制御 できることになる。

\section{3 体動に応じた体表点分布の再計算}

長時間の診断の間患者の体は呼吸などによって動き，また 医師の指示によっては超音波画像を取得しやすい角度に体を 傾けることもある.よって患者の体動が生じた場合に体表面 

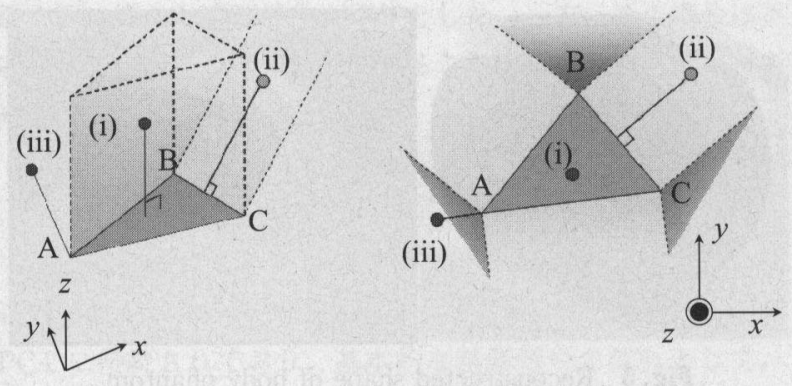

Fig. 7 Calculation of distance between the probe and body surface

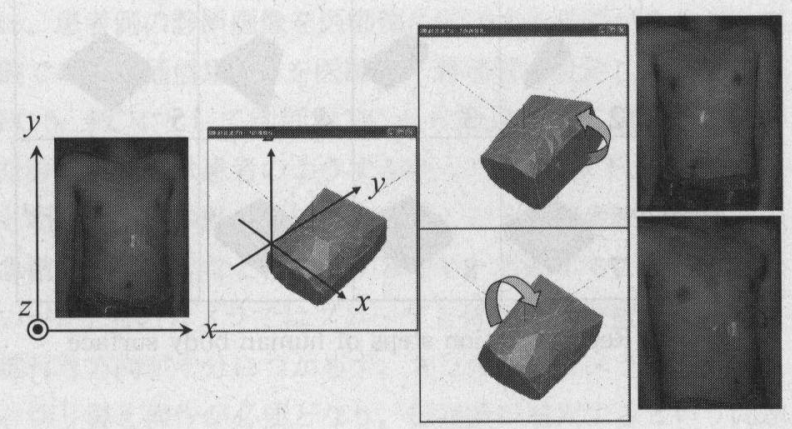

Fig. 8 Reconstructed body surface before and after body motion

の形状を更新し，プローブと患者の位置関係を常に把握する ことが必要となる.ここで鳩尾の基準点を $O$ 点とし, 患者 の呼吸や体動による 0 点の変化に応じて, それまでに得ら れたすべての体表点 $P_{i}$ を更新する. 具体的には $O$ 点の平行 移動と回転から並進行列 $\boldsymbol{T}$, 回転行列 $\boldsymbol{R}$ を求め, (1)式に 示す演算によって得られた座標 $P_{i}^{\prime}$ を, 体動を反映させた体 表点とする.

$$
P_{i}^{\prime}=\boldsymbol{R}\left(P_{i}-O\right)+\boldsymbol{T}
$$

実際に被験者の体動に応じた体表面の変化を検証し た ${ }^{19), 20)}$. 被験者に体軸中心に約 20 度回転してもらい, その ときの体表面形状を再計算させた結果を Fig. 8 に示す。こ れより患者の体動を反映した体表が描けており，さらに体動 を反映した後の体表とプローブの位置関係が対応しているこ とも確認できた.

\section{6. プローブ接触力に応じた映像品質制御}

\section{1 複数映像の優先度に対する検討}

患者映像と超音波画像の 2 系統の映像のうち, プローブと 体表が離れた状態では超音波画像には何も映らず, プローブ が体表に接触中は, 患者映像は静止画もしくはフレームレー トの遅い映像で十分である.そこで, Fig. 3 の(3)に示したプ ローブ先端の体表面接触力を $\mathrm{PC} 4$ にも反映させ, 必要な映 像の優先度を自動的に判断する映像品質制御 ${ }^{19)}$ を実現した.

Fig. 3 の PC 3 におけるインターフェース画面を Fig. 9 の ように構築した。（a）が優先度の高い映像 (main image), (b)が優先度の低い映像 (sub image)であり, 患者映像およ

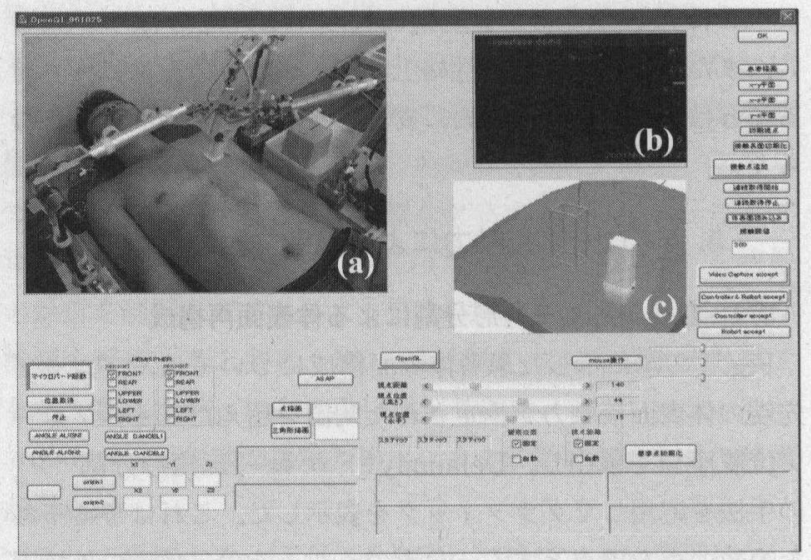

Fig. 9 The whole view of the interface

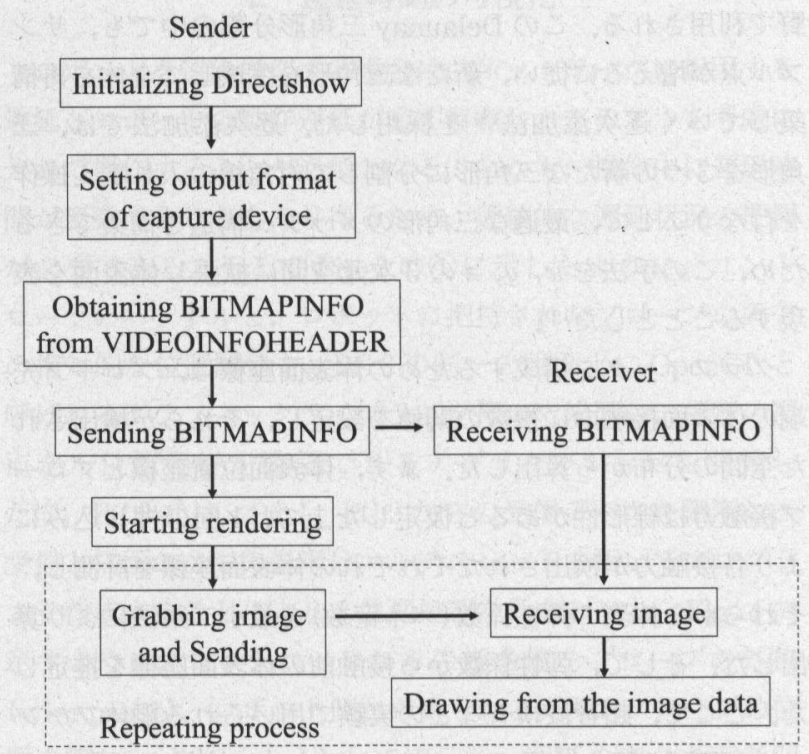

Fig. 10 Flowchart of image communication

び超音波画像のいずれかが映し出される。（c）はプローブと 体表面を再構成した CG 映像である。（c）はコントローラ側 からの位置指令，ロボット側で得られたプローブ位置，接触 力, 体表点などのすべてのデータの集大成である.また (c) は (a)の患者映像に合わせて視点や光源の切り替えが可能で ある.さらに作成した体表面の保存・読み込みにより，診断 中に突然プログラムが落ちた，ロボットが誤作動を起こした など，何らかのアクシデントによりシステムの再接続が求め られたときでも，再び体表面再構成のための操作を行なう手 間を省き，即座に通常の診断操作に戻ることができる.

\section{2 映像通信の流れ}

映像通信のプログラムにはDirectShowを用いた。DirectShow は, Microsoft 社のWindows 用マルチメディア拡 張 API 群である DirectX に含まれる API の 1 つであり，動 画や音声などの大容量のマルチメディアデータをストリーミ ング再生(データを読み込みと同時に再生)することができ る. 
Fig. 10 に通信を組み合わせたビデオキャプチャの流れを 示す.キャプチャデバイスで入力された映像は DirectShow により BYTE型の画像データに外部出力し, Bitmapに変 換して表示した. Bitmap 表示を行なうためには，BYTE 型 の画像データのほかに, Bitmap の情報を示す BITMAPINFO 構造体が必要となるが, ビデオへッダに Bitmap 情報が 含まれるので，ビデオへッダより BITMAPINFOを取得す ることで描画が可能となる。映像通信を行なう際にも, BITMAPINFO と画像データの二種類を送信して受信先で 描画を実行する。その場合，使用できる通信帯域を設定し， その上で画像サイズ, フレームレート, 圧縮率により算出さ れたデータレートが通信帯域を越えないように制御を行な 3 .

\section{32 系統の映像間の品質制御}

実際の遠隔診断において考えられる状況を以下の 3 パ夕ー ンに分類して定義し，それぞれの状況において 2 系統の映像 の相対的な品質を Table 1 に示すように制御した。

Situation 1 : 患者映像と CG を観察しながら，プローブを 当てる位置を探索

Situation 2：プローブを体表面に接触させ，超音波画像と 患者映像の両方を観察しながらの微調整

Situation 3：超音波画像のみを観察しながら，医師の経験 に基づくプローブ操作と診断

これらの状況間の遷移を表わすフローチャートを Fig. 11 に示す。まず診断開始から初期の状態では Situation 1 に設 定されており，プローブが距離 Lより体表に近づき，かつ 軽度の接触力の絶対值 F 1 が加わると Situation 2 に移行し, さらに診断に必要な接触力 F 2 が加わると, Situation 3 に 移行する。また，どの診断状況においてもプローブが L 以 上体表から離れると Situation 1 に戻るように設計した. 5.2 節で述べた体表面距離を考慮する理由は，接触力のみではた とえば患者の腕など，体表面以外の部位がプローブに当たつ た場合に状況を誤認識する恐れがあるため，状況判断に組み 入れた。

ここで, 実際に診断し診断状況が移行することによる映像 品質の変化を観測するため，2系統の映像の転送速度を計測 した．遠隔超音波診断で必要なリアルタイム映像の通信手法 に関してさまざまな検討21) 23) がされているが，ここでは通 信帯域幅を $5 \mathrm{Mbps}$ に設定し, 患者映像はフルカラー, 超音 波画像はグレースケールで両者とも $320 \times 240$ pixel の非圧 縮の映像のフレームレートを変化させた。前述した各パラ メー夕を F $1=100 \mathrm{gf}, \mathrm{F} 2=200 \mathrm{gf}, \mathrm{L}=40 \mathrm{~mm}$ とし,まず プローブを体表面から離れた空中で操作，30秒経過後プ ローブを体表に軽く接触させ,さらに 30 秒経過後診断に必 要な状態までプローブを押し込み転送速度の変化を計測し た.この測定結果を Fig. 12 に示す.これより接触力と体表 面距離から診断状況が自動的に認識され，各映像の品質制御 が行なえていることが確認できた.
Table 1 Situations and settings

\begin{tabular}{|c|c|c|c|}
\hline & Situation1 & Situation2 & Situation3 \\
\hline main image & patient scene & echogram & echogram \\
\hline sub image & echogram & patient scene & patient scene \\
\hline main : sub & $10: 1$ & $1: 1$ & $10: 1$ \\
\hline
\end{tabular}

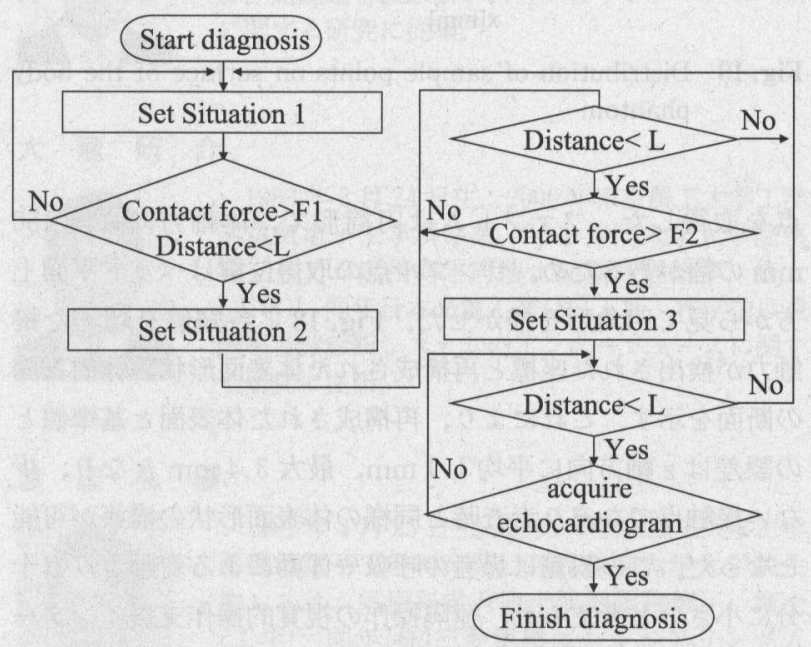

Fig. 11 Flowchart through situations

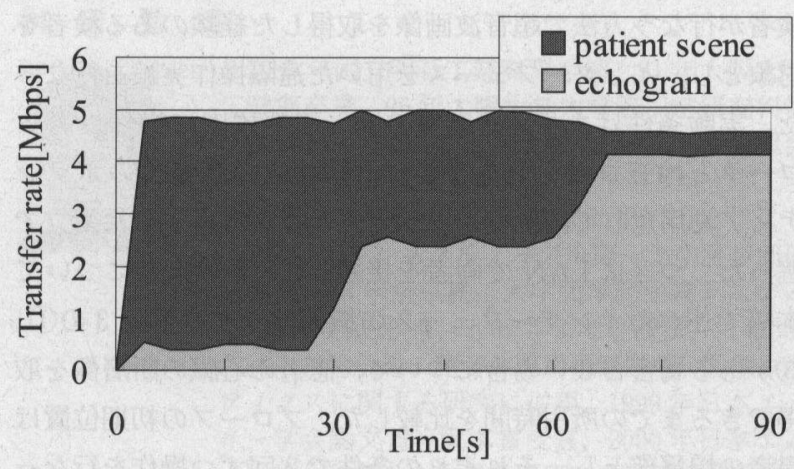

Fig. 12 Transfer rate based on situation change between echogram and patient scene

\section{7. インターフェースの機能評価}

\section{1 体表面グラフィックの精度検証}

5.1 節で述べたようにプローブの接触によって形状が変化 した体表面形状から，接触前の体表面の再現性について精度 検証を行なった。検証にはFig. 5 に示したファントムを用 いて, 接触力の閾值は 5.1 節と同様に $100,300,500 \mathrm{gf} に$ 設定した.まず前述した磁気式 3 次元位置センサを用いて, ファントムを変形させないように外周をなぞり,その形状の 基準値とした。つぎに患者側の検査ロボットを用いた遠隔診 断時の計測系により，ファントム表面の計 12 点のサンプル 


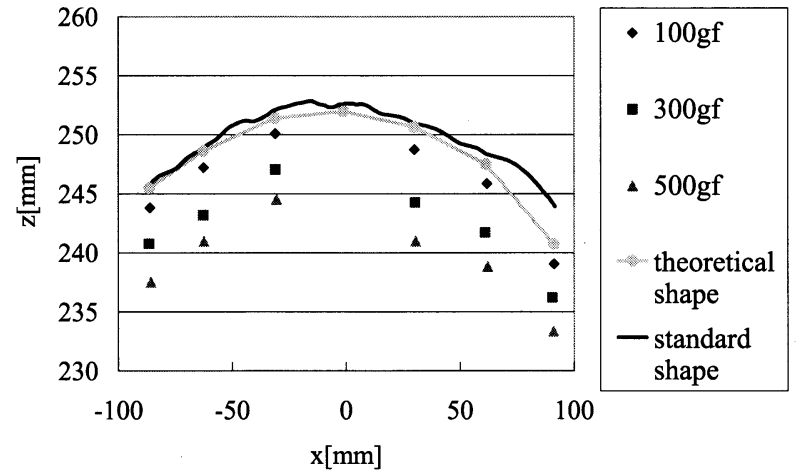

Fig. 13 Distribution of sample points on surface of the body phantom

点を取得した. ファントムは円筒形で，体軸方向に約 150 $\mathrm{mm}$ の幅があるため, サンプル点の取得位置はベッド平面上 方から見て四角形を描かせた. Fig. 13 に各閾值を超えた接 触力が検出された座標と再構成された体表面形状の体周方向 の断面を示す.これにより, 再構成された体表面と基準值と の誤差は $\mathrm{z}$ 軸方向に平均 $1.1 \mathrm{~mm}$, 最大 $3.4 \mathrm{~mm}$ となり, 少 ない接触点でなぞり走查時と同様の体表面形状の構築が可能 となった。この誤差は患者の呼吸や体動による変動よりも十 分に小さいと考えられ, 遠隔操作の視覚的操作支援インター フェースとして信頼可能な值を満たしている.

\section{2 本インターフェースの操作性の検証}

本インターフェースの操作性を検証するため通常の超音波 検者が行なう方法で超音波画像を取得した経験のある検者を 対象とし，インターフェースを用いた遠隔操作実験を行なっ た. 実験条件はまず, 研究室の同一の部屋内に操作コント ローラと検査ロボットを設置し, 仰臥位の患者役のボラン ティアを用意して医師側から患者側が見えないように衝立で 遮った.つぎに LAN で両者を接続し，5名の検者について 本稿で述べたインターフェースの機能, つまり Fig. 3 の(1)(3)がある場合とない場合について, 患者の心臓の断層像を取 得できるまでの所用時間を比較した. プローブの初期位置は 患者の沜尾部とし, それぞれの条件で 2 回ずつ操作を行なっ たときの所要時間の平均結果を Fig. 14 に示す.

Fig. 14 より，インターフェースを用いた場合のほうが所 要時間の減少が見られた．特にグラフィック環境を使用し， ある程度の位置を把握することで, 目的の位置に操作するこ とが容易であるため, 1 回目より 2 回目が全員所要時間の減 少が見られた。また，患者映像だけではプローブの体表への 接触判定があいまいであったが，インターフェース導入時で は Situation 1 から自動的に Situation 2 に移行することによ り，映像が切り替わるため接触状態が明確となった。それぞ れの平均值の差について検証を行なうため有意差検定を実施 し, 両側検定の危険率 $1 \%$ 未満を有意差ありと判定した. そ の結果, 1 回目は $\mathrm{p}<0.005,2$ 回目は $\mathrm{p}<0.001$ となり, 共 にインターフェースの有無による心蔵の断層像取得時間に統 計学的有意差が認められた。この結果より本インターフェー

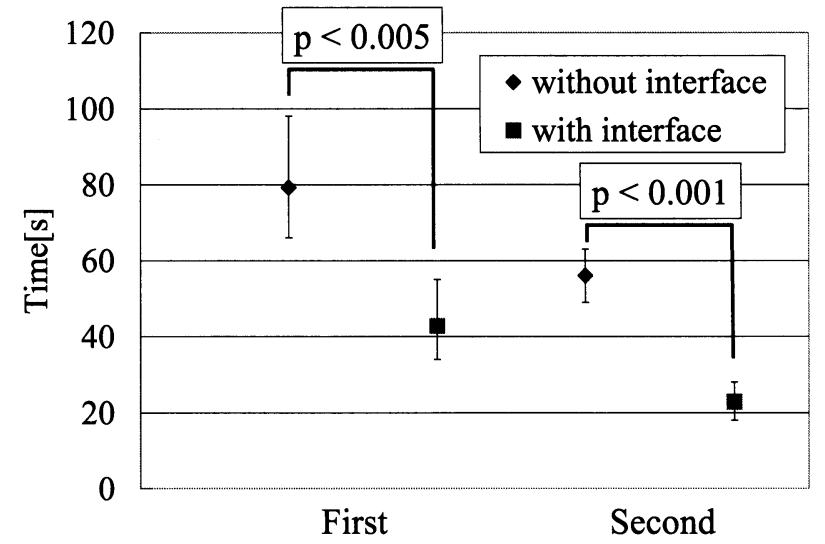

Fig. 14 Time required for examiner to acquire echocardiogram with and without interface

スによる操作性の向上が見られ, 遠隔超音波診断システムに おける有効性が示された。

\section{8. むす び}

遠隔超音波診断において, 患者側から得られる遅延時間と 体表面接触力の情報をもとに, グラフィックを駆使したイン ターフェースを医師側に構築した。 これにより，個々の患者 の体型を反映し，プローブと患者の位置関係を常に確認しな がらの操作が可能となり, 操作性が大幅に向上した。また診 断状況の認識による映像の品質制御により, その状況で重要 度の高い映像を精細に表示することができた，今後は，ネッ トワークの遅延が大きく生じる実験系に対しても検討を行 なった上で, 実際に医師の操作実験を経てさらに性能を向上 させる.

\section{参 考 文 献}

1) M. Blaivas, M. Lyon and S. Duggal : Ultrasound image transmission via camera phones for overreading, Am. J. Emerg. Med., 23, 433/438 (2005)

2）末永, 飯野, 黒田, 大城, 千原：遠隔超音波画像診断におけるプ ローブ操作教示システム, 電子情報通信学会論文誌, J83D2-1, 324/332 (2000)

3）青木, 大籠, 小山田, 金子, 栘田：超音波検査ロボットによるプ ローブのなぞり走査のための体表面粘弾性特性解析法, 第 25 回日本ロボット学会学術講演会論文集, CD-ROM (2007)

4) K. Masuda and H. Kato : Development of a Twist Pantograph Mechanism for Robotic Tele-echography, Proc. of 3rd European Medical \& Biological Engineering Conference, 1661/1664 (2005)

5) N. Koizumi, S. Warisawa, H. Hashizume and M. Mitsuishi: Dynamic switching capability of the controller according to diagnostic tasks in the remote ultrasound diagnostic system, in Journal of Robotics and $\mathrm{Me}$ chatronics, 16-2, 146/154 (2004)

6）小泉，割澤，橋詰，光石：遠隔超音波診断システムにおけるス レーブ姿勢の Continuous Path 制御系, 日本ロボット学会誌, 23-5, 619/628 (2005)

7) A. Vilchis, J. Troccaz, P. Cinquin, K. Masuda and F. Pellissier: A New Robot Architecture for Tele-Echography, IEEE Transaction on Robotics and Automation, 
19-5, 922/927 (2003)

8) P. Abolmaesumi, S. E. Salcudean, W-H. Zhu, S. P. DiMaio and M. R. Sirouspour : A User Interface for Robot-Assisted Diagnostic Ultrasound, IEEE Proc. ICRA, 1549/1554 (2001)

9）野本, 杪田：3 次元ワイヤ駆動による遠隔超音波診断のための 力覚付き操作ハンドルの開発, 生体医工学, 44-1, 213/220 (2006)

10）渡辺，杪田，木村：遠隔超音波診断システムのための遅延時間 可視化インターフェースとその評価, 第 26 回医療情報学連合 大会講演論文集, CD-ROM (2006)

11）大籠, 小澤, 野本, 栘田：パラレルワイヤ駆動コントローラに よる遠隔操作の安全性向上のための仮想反力生成制御，第 17 回日本機械学会バイオフロンティア講演会論文集, $15 / 16$ (2006)

12）川村, 木野, 崔, 勝田：パラレルワイヤ駆動システムにおける ワイヤ座標系制御法, 日本ロボット学会誌, 16-4, 546/552 (1998)

13）栘田, 加藤, 野本, 渡辺, 原田, 竹内：パンタグラフ型超音波診 断ロボットの軽量化と走行する救急車一病院間での遠隔診断 実験, 第 23 回日本ロボット学会学術講演会論文集, CD-ROM (2005)

14）森, 司, 堀, 黒田, 吉原：遠隔医療のためのアプリケーションレ ベルのネットワーク QoS 制御システム, 生体医工学, 42-4, $340 / 346$ (2004)

15）山本, 内山, 田村 : 3 次元形状モデリングのためのドロネー網 生成法, 電子情報通信学会論文誌, J78-D-II-5, 745/753 (1995)

16) N. Amenta, M. W. Bern and M. Kamvysselis: A new voronoi-based surface reconstruction algorithm, In SIGGRAPH, 415/421 (1998)

17) Z. B. Azouz, M. Rioux and R. Lepage: $3 d$ description of the human body shape using karhunen-loeve expansion, Int'l J. Information Technology, 8-2, 26/35 (2002)

18）㴊田, 鹿嶋, 中村, 森, 村島 : 逐次添加法による 3 次元離散ボロ ノイ図の作成と自己組織化特徵写像への応用, 電子情報通信 学会論文誌, J87-D-II-2, 387/398 (2004)

19）堀口, 大籠, 青木, 金子, 桝田 : 複数映像間の相対的品質を考慮 した遠隔超音波診断インターフェースの開発，日本超音波医 学会基礎技術研究会資料, 2007-4, 39/42（2007）

20)大籠, 堀口, 栘田 : 体表面接触力を考虑した遠隔超音波診断イ ンターフェースの開発，第 50 回自動制御連合講演会論文集, $511 / 513(2007)$

21）楳田,黒田，大城，千原：実時間医用超音波動画像伝送システ 么の提案, 電子情報通信学会技術研究報告, 99-392, 1/6 (1999)

22) J. Pyke, M. Hart, V. Popov, R. D. Harris and S. McGrath : A Tele-ultrasound System for Real-time Medical Imaging in Resource-limited Settings, Proc. of the 29th Annual International Conference of the IEEE EMBS, 3094/3097 (2007)

23) M. G. Martini, R. S. H. Istepanian, M. Mazzotti and N. Philip : A Cross-Layer Approach for Wireless Medical Video Streaming in Robotic Teleultrasonography, Proc. of the 29th Annual International Conference of the IEEE EMBS, 3082/3085 (2007)

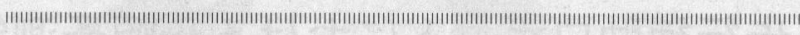

$$
\text { [著 者 紹 介] }
$$

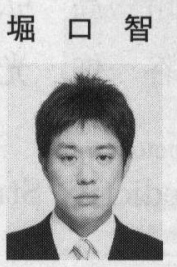

洋（学生会員）

1985 年 2 月 16 日生. 2007 年東京農工大学工学 部電気電子工学科卒業. 同年同大学大学院生物シ ステム応用科学府博士前期課程入学. 現在に至 る. 遠隔超音波診断システムのインターフェース に関する研究に従事。

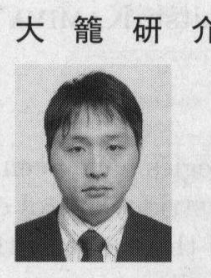

1983 年 3 月 24 日生. 2006 年東京農工大学工学 部電気電子工学科卒業. 2008 年同大学大学院生 物システム応用科学府博士前期課程修了, 修士 (工学). 同年日本光電工業 (株) 入社. 在学中は遠 隔超音波診断システムのインターフェースに関す る研究に従事.

\section{渡 辺弘 樹}

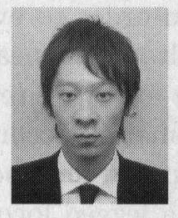

1981 年 4 月 25 日生. 2005 年東京農工大学工学 部電気電子工学科卒業. 2007 年同大学大学院生 物システム応用科学府博士前期課程修了, 修士 (工学). 同年(株)三菱電機エンジニアリング入 社. 在学中は遠隔超音波診断システムの通信手法 に関する研究に従事.

\section{栘田晃司}

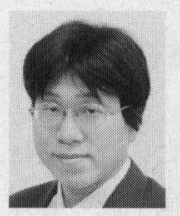

1989 年国立明石工業高専卒業, 91 年大阪大学 工学部卒業, 96 年大阪大学大学院工学研究科博 土課程修了, 博士(工学). 96 年日本学術振興会 特別研究員 (国立大阪病院), 同年名古屋大学工学 部助手, 99 年愛媛大学医学部助手. 2002 年より 1 年間, フランスグルノーブル第一大学医学部研 究員. 2003 年東京農工大学大学院生物システム 応用科学府助教授, 2007 年より准教授.この間, 生体内薬物伝送, 超音波医用画像処理, 医療口ボ ティクスに関する研究に従事. 1999 年日本エム イー学会論文賞・阪本賞受賞, 2000 年日本エム イー学会秋季大会にて若手研究者最優秀賞受賞. 2002 年日本超音波医学会より超音波工学フエ ロー授与. IEEE EMBS, 日本生体医工学会, 日 本超音波医学会, 電子情報通信学会, 日本ロボッ ト学会などの会員. 